Deckers J. Fairness in Newcastle: Theory and Practice. In: Davoudi, S; Bell, D, ed. Justice and fairness in the city: A multi-disciplinary approach to 'ordinary' cities. Bristol: Policy Press, 2016, pp.249-264.

\title{
Publisher website
}

https://policypress.co.uk/justice-and-fairness-in-the-city

ePrints link

http://eprint.ncl.ac.uk/224547

Date deposited

$21 / 02 / 2018$

\section{Copyright}

This is a post-peer-review, pre-copy edited version of a chapter published in Justice and fairness in the city: A multi-disciplinary approach to 'ordinary' cities. Details of the definitive published version and how to purchase it are available online at: https://policypress.co.uk/justice-and-fairness-in-thecity 


\section{Fairness in Newcastle: Theory and Practice}

Jan Deckers

This text is the author's own version of chapter 13 published as follows:

Deckers, J. Fairness in Newcastle: theory and practice. In: S. Davoudi and D.

Bell (eds.) 2016. Justice and fairness in the city. A multi-disciplinary approach

to 'ordinary' cities. Bristol: Policy Press, 249-264 (Chapter 13).

\section{Introduction}

In 2011, Newcastle City Council set up the Newcastle Fairness Commission (NFC), a group of eighteen people who were invited to prepare a report with the aim to set out the principles that would help Newcastle to become a fairer city. The NFC, which was chaired by Chris Brink, the vice chancellor of Newcastle University, published its report in 2012 (Newcastle City Council and Newcastle University, 2012). This article engages with what this report has to say about how salaries ought to be allocated within organisations, which it recognises as an important dimension of fairness. More specifically, the author shall engage with the question whether or not the theoretical recommendations made in the report ought to guide the practical allocation of financial resources in Newcastle University, the organisation that the author works for, and the third biggest employer in the city of Newcastle. The author's focus on Newcastle University stems from the belief that, as an employee, he has a greater right and duty to contribute to financial reform in his own than in other organisations. Whereas the author shall not seek to argue for this position, which is based on his belief in participatory democracy, his hope is that these views will also inspire financial reform elsewhere. 


\section{A critical evaluation of the work of the Newcastle Fairness Commission}

The NFC recognises that Newcastle is a relatively poor city, which it takes to be shown, for example, by the fact that it has more than 70,000 people who live in the $10 \%$ most deprived areas in the country, a relatively large proportion of people with significant debts, a relatively large proportion of children living in poverty, and an estimated 30\% of households who suffer from fuel poverty (Newcastle City Council and Newcastle University, 2012: 11). The region also has a higher rate of unemployment compared to the national average. Whilst life expectancy is generally lower than the national average, some parts of the city suffer some of the highest rates of morbidity and mortality in the whole of the United Kingdom. The difference in life expectancy between some who live in some areas of the city and some who live in others exceeds 14 years (Newcastle City Council and Newcastle University, 2012: 11).

The question might be asked how these facts relate to fairness. The author has argued elsewhere that the question of what is fair can be conceived entirely in terms of the question of what is, very broadly conceived, fair health care, and the author argued for granting all human beings a right to health care (Deckers, 2011). Whilst these arguments shall not be elaborated on here, it is interesting to note that a similar right is affirmed by article 25 of the Universal Declaration of Human Rights, which states that 'everyone has the right to a standard of living adequate for the health and wellbeing of himself and of his family, including food, clothing, housing and medical care and necessary social services'. Whereas this claim is problematic as even very high living standards may not be sufficient to support good health, the author believes that the NFC is nevertheless correct to infer unfairness from observed differences in the morbidity and mortality of different populations. Recognising that many, if not most people cannot enjoy good health unless others provide food, water, sanitation, shelter, and other health services or - within the prevailing capitalist economy - 
the financial means to secure these, the question of what is fair is therefore intimately connected with, but not limited to, the question of what would be a fair distribution of financial resources.

The NFC recognises that the distribution of financial resources is not merely an absolute, but also a relative concern. Indeed, a large body of empirical research supports the view that a person's right to health care can not only be threatened by an absolute, but also by a relative lack of resources (Marmott et al, 1991; Daniels, 1999; Wilkinson and Pickett, 2010). Knowing where one is in 'the pecking order', the economic rank one occupies within a society or organisation, appears to be associated with a greater probability of suffering poor health when one is relatively low down and with a smaller probability of suffering poor health when one is relatively high up in the ranking order. In addition, empirical evidence supports the view that, all else being equal, people who live in more unequal societies have a greater chance of experiencing poor health compared to people who live in more egalitarian societies (Wilkinson and Pickett, 2010).

In light of these concerns with absolute and relative poverty, the NFC advocates 'reductions in the pay ratio between the highest and the lowest paid within companies' (Newcastle City Council and Newcastle University, 2012: 39). The question must be asked, however, why we should allow pay gaps to exist in the first place. One alternative view is that we should pay everyone equally for each hour that they work. This egalitarian perspective is adopted by Suma, a cooperative company based in Elland, in the north of England (Corbett, 2013). Unlike Suma, the NFC adopts a sufficientarian view that allows some pay inequalities provided that those who are paid the least receive a living wage. In this, it follows a recommendation by the Living Wage Advisory Panel, set up in 2011 by Newcastle City 
Council. The Panel produced a report in 2012 that defines a living wage as 'the level of income needed to provide an acceptable standard of living in Britain to ensure good health, adequate child development and social inclusion' (Living Wage Independent Advisory Panel to Newcastle City Council, 2012: 3). This interest in a living wage is placed within the wider context of 'the election manifesto of the party that became the ruling group in May 2011' which 'made an explicit commitment to implement a Living Wage' (Living Wage Independent Advisory Panel to Newcastle City Council, 2012: 4). However, a similar commitment is shared much more widely, and can be found also in the 1961 European Social Charter of the Council of Europe, which stipulates a 'right of workers to a remuneration such as will give them and their families a decent standard of living' (European Social Charter of the Council of Europe, undated, part 2, article 4).

In line with more recent developments that have taken place elsewhere in relation to this proposed right, the panel expressed the view that the national living wage rate promoted by the Living Wage Foundation, which stood at $£ 7.20$ per hour at the time of publication, 'should be adopted in Newcastle' (Living Wage Independent Advisory Panel to Newcastle City Council, 2012: 11). This has now risen to $£ 7.85$, exceeding the national minimum wage, which varies with age and which was first introduced in the United Kingdom in 1999. Subsequent to the publication of the panel's report, the living wage was implemented by Newcastle City Council on 1 November 2012 (Newcastle City Council and Newcastle University, 2012). Whereas many other organisations have taken similar initiatives, a 2013 report revealed that about $20 \%$ of UK workers were still paid hourly rates below the living wage (Whittaker and Hurrell, 2013). 
There is no doubt that the implementation of a living wage as a minimum threshold that every employee should be earning per hour of paid work might help to secure the right to health

care for those who were being paid less than that beforehand. However, someone who is inspired by the writings of John Rawls might argue that, other morally significant factors being equal, income and wealth should ideally be divided equally unless paying workers unequally would confer a greater index of 'primary goods' (that is, morally significant goods that every rational human being can be assumed to want) over the lifetime of the least advantaged (Rawls, 1999: 266). Whereas it has been argued that, in reality, this view might be 'compatible with a bewildering array of distributive outcomes ... ranging from total equality to stark inequality' (Arnold, 2012: 105), Gerald Cohen (1997) has argued that Rawls's ideal society is inconceivable without assuming that its citizens would be driven by an egalitarian ethos. As Suma's pay structure exemplifies such an ethos - without wishing to make the claim that Cohen would necessarily have endorsed such a structure - the author shall engage in what follows with the question of whether or not Newcastle University might have good reasons to deviate from the egalitarian position adopted by Suma, which shall henceforth be referred to as the egalitarian baseline.

\section{How to justify wage differentials within Newcastle University}

One reason that might be proffered to justify differentiated wages is that some people are more successful at converting their efforts into goods and services that other people need or desire, and that their success should be allowed to be reflected in their wages. The modern world seems to be built - in very large measure - on this assumption. Bill Gates became very rich because he was able to develop products that many people desire. Those who adopt the view that success deserves to be rewarded might say that Gates deserves his riches on the basis of his success. 
The problem with this view is that success is a relative notion. A farmer may be skilful at producing a great crop of potatoes, but he might still not be successful if there is an abundance of potatoes on the market in that particular season so that there would be little demand for them. Similarly, Gates might not have been successful if other people had either saturated the market with similar software before he had developed his, or been more fortunate to have the means to market the software that they had developed. In light of the fact that success depends on factors that are beyond one's control, it seems arbitrary to reward success. Even if some of these factors could be controlled, for example by providing similar marketing opportunities to all, it remains unclear why success ought to be rewarded. For example, it is unclear to the author why the success of those who are able to produce pornographic films that appeal to many people ought to be rewarded as not all things that people are willing to pay for are necessarily in the interests of a good society.

Similar problems surround the view that it is not success, but talent that ought to be rewarded. Some people may never be granted the opportunities to show or develop their talents so that they are not rewarded for them. Even if these opportunities could be equalised, some may be very talented in producing goods and services that do not contribute to the good life whilst others may produce goods and services that are not in demand, but that would nevertheless be very good for humanity. Think, for example, of a very talented scholar at a university who produces a brilliant new theory, but whose theory is rejected and therefore never published because it clashes with the fashion of the day. The author concludes that success and talent depend largely on genetic, environmental, or social factors that are beyond one's control, and that they therefore do not provide good bases to reward people. 
Perhaps effort - which the author defines in relation to either the disposition to work hard or the willingness to take on relatively high risks - provides a good reason why some people merit a higher income than others. Those who support this line of reasoning might argue that some people either work harder than others or take on greater risks, and that it would not be fair to refrain from rewarding them for their greater efforts, at least where the means are available to do so. Both $\mathrm{X}$ and $\mathrm{Y}$ may have an interest in receiving a high income, but only $\mathrm{X}$ may give this interest such importance that he would be prepared either to work hard for it or to take significant risks. Y, on the other hand, may value other things, and may not be prepared to make that much effort. It could therefore be argued that $\mathrm{Y}$ would not be wronged by being provided with a smaller income as he does not take an interest in working very hard or taking significant risks. Intuitively, this view seems attractive as it suggests that people can autonomously choose to earn more than others if they wish to do so. However, apart from the fact that rewarding effort per se does not guarantee that all have equal opportunities to make similar efforts, this scheme is not free from other problems.

A first problem is that effort per se does not seem to be sufficient to warrant pay differentials. It is plausible to hold that some efforts that are made to produce or provide some things are more worthwhile than others, even if the efforts that are made may be equal. If $\mathrm{X}$ works very hard at producing goods or providing services that do not contribute much to the common good, or perhaps even undermine it, it does not seem to be right to reward him for his efforts. This creates the problem of distinguishing between things that contribute to the common good and things that do not do so, which may be difficult in a pluralistic society. However, it is not because this is a difficult task that it should not be carried out. Many may agree, for example, that those who work hard to produce pornographic films do not contribute to the 
common good, contrary to university scholars who put a lot of effort into educating people or nurses who risk being infected whilst caring for Ebola victims.

Whereas establishing agreement on what sorts of things should count as positive efforts towards the common good in a pluralistic society might not be an insurmountable barrier, this does not solve all problems. A second problem is that there may be natural and cultural differences in people's capacities to work hard or to take on significant risks for the common good. Some may not be able to do so because of genetic factors that are beyond their control. Others may have been subjected to social factors that have predisposed them to be less prepared to work hard or to take on significant risks for the common good. Unless it could be decided to what extent someone's relative laziness or risk aversion was not the product of natural or social factors, it would seem to be unfair to discriminate against those who are either lazier or more risk averse through no fault of their own.

A third problem is that any proposal to reward effort for contributions to the common good by financial means runs the risk of providing an incentive for people to contribute for the wrong reason and may diminish people's motivation to contribute for the right reason. To use an example provided by Michael Sandel (2012: 9), if reading is something that is valued as a common (as well as a private) good, some might want to incentivise children's efforts to read books by rewarding them financially. The children may thus learn to appreciate reading not for its own sake, but merely for the fact that it provides a means towards receiving financial benefits. Even if children may improve their reading abilities by such a scheme, it might be argued that they would have been improved for the wrong reason, and that their overall development would have been stinted by the extrinsic incentive. Although some children may learn to appreciate reading for its own sake, this does not imply that the means by which they 
learnt to do so were appropriate. Some may have learnt that it is good to do particular things simply because they make money, rather than because they ought to be valued for their own sake.

In light of these problems, some might argue that we should sever all links between salary and success, talent, or effort, and that one's salary should be determined merely by one's needs. Those with greater needs would receive more money, regardless of their success, talents, or efforts at contributing to the common good. Provided that what counts as a need is subjected to social scrutiny rather than personal whim, this view seems attractive. The view that someone with a greater metabolic rate should be allowed to consume more food compared to someone with a lower metabolic rate, for example, seems intuitively defensible. However, the author is not convinced that we ought to relinquish altogether the idea that rewarding controllable effort for the common good should be permissible. To return to the example provided earlier, it would seem wrong to refrain from incentivising reading if it would undermine the common good more than doing so. Many activities, including reading, are not merely valuable for their own sake. If someone valued the ability to read a foreign language because they would be in a better position to do business with people who speak that language, it would seem to be prudent for a financial manager - who is conceived of here as a person with legitimate control over an organisation's finances - to incentivise the person in question financially for their commitment to learn that language if they expect that the incentive will produce greater contributions to the private good of the firm. Provided that the firm's private good also serves the common good, it would seem hard to oppose this unless it could be argued that the common good could be served better otherwise. Similarly, if some staff are expected to work during hours that might undermine their health more, for example night time work or weekend work that might interfere negatively with people's interests in, 
respectively, rest and social opportunities, it would be reasonable to pay them more to compensate for the extra health risks that they take on by working during those hours so that they might be able to reduce their working hours. If this is accepted, some workers should be allowed to receive more income per hour worked compared to others on the basis of their greater controllable efforts for the common good, regardless of whether or not they have greater needs.

It is clear that rewarding controllable effort makes sense where it promotes the common good more than not doing so, unlike rewarding success, as the former does not depend on the arbitrary nature of the latter. However, in practice, it will often be the case that success is a necessary condition to justify rewarding controllable effort. An organisation that makes only just enough profit to be able to stave off absolute poverty for its employees, for example, would do well to disregard payment on the basis of controllable effort as using such a principle might condemn some employees to absolute poverty. It must therefore be pointed out that the author has only argued that rewarding workers for their controllable efforts for the common good can be justified, not that such efforts necessarily must be rewarded.

If we apply this line of thinking to Newcastle University, the author concludes that justice does not demand that it would be wrong for some to receive a nett hourly salary that exceeds the amount that other workers receive per hour worked. However, whilst the University's Council - which has the primary responsibility to control the University's finances - would do well to honour those who go to great lengths to pursue the private good of the University (and the Government would do well to avoid taxing them if it does not clash with the common good), any wage differentials that are either maintained or implemented to honour hard workers should also reflect the valid points that Rawls makes where he points out that 
the amount of effort one makes is influenced by factors beyond one's control, including 'family and social circumstances' (Rawls, 1971: 74), as well as 'natural abilities and skills' (Rawls, 1971: 312; Rawls 1999: 273-4). As it may be hard to determine to what extent someone's decision to make greater than average efforts is caused by voluntary choice or by involuntary factors, any concrete schemes to differentiate wages on the basis of controllable effort must be careful to avoid crossing the thin line between rewarding people fairly and discriminating unfairly.

Accordingly, the University should adopt a rigorous system to incorporate the 'controllable effort' factor, for example a revised annual 'performance development review', so that those who either are expected to make or have made more controllable efforts compared to others are rewarded appropriately. This is not an argument for allowing people to be rewarded for the work that they do beyond the number of hours for which they are contracted. If some people are routinely working more hours than the number for which they are contracted, then this is their voluntary choice. To the extent that the voluntariness of any such choice is compromised by informal expectations, a case should be made for an increase in the number of contracted hours, rather than for a pay rise to compensate for the hours worked beyond one's contract.

Controllable effort, however, should not be the only factor that should be taken into consideration by the University's Council. There are a number of reasons why further deviations from the egalitarian baseline are appropriate.

Firstly, the egalitarian baseline does not taken into account that workers contribute unequally to the common good through the unpaid work that they carry out to benefit those to whom 
they owe a duty of care. Many societies across the world fail to pay people for much of their productive activity, for example for many tasks carried out within their families. The UK Government is no exception. Many people who are not actively seeking (many hours of) paid work because of their caring duties are not being provided with any direct financial assistance to fulfil those duties, for example people who look after elderly relatives who may have significant health care needs (Pickard, 2015). As women carry out more unpaid work than men, the injustice associated with unpaid work has been an important feminist issue (Himmelweit, 1995). It may account at least in part for why few women can be found amongst more senior staff at universities in the UK and elsewhere (Morley, 2014).

The critic might point out that these issues are for the Government to resolve, and should not concern an organisation such as Newcastle University. This, however, is too simplistic. Consider a father who provides equal amounts of financial support to his children, where only one of the children has morally significant duties to someone who needs that child's financial support for their survival. Imagine that this resulted in significant hardship for the child in question. It would seem to be wrong for the father to provide his children with equal amounts of money, and it would seem to be right that he provides more support for the child with the needy dependant. By analogy, it might be said that every organisation owes a special duty of care towards its workers by virtue of the work ties that connect colleagues. As workers with morally significant unpaid duties may find it harder to enjoy a certain level of health care compared to others because of these duties, Newcastle University's Council ought to be particularly concerned about the wellbeing of these workers if it adopts the view that it has an equal duty of care towards all its workers. 
This does not undermine the fact that workers must advocate political change so that those who are currently not being paid (sufficiently) for their contributions to the common good are rewarded by the UK Government, as well as advocate for financial reform in other jurisdictions, which might, for example, be in the form of securing a basic income for all people - as proposed, for example, by the Basic Income Earth Network (Basic Income Earth Network, undated). However, as long as insufficient political change has taken place at the level of the national government, Newcastle University's Council must ensure that all its workers are able to enjoy a certain standard of health care, rather than cater disproportionately for those who have relatively few unpaid duties. Accordingly, the University must differentiate wages to give due consideration to the different morally significant duties that its staff have in relation to unpaid work.

Secondly, the University must also recognise that some staff members may have had to spend a lot of money in order to receive the qualifications that make them suited for their jobs. To the extent that these qualifications were paid for by the workers themselves, who may need to pay back loans that they have taken out whilst they studied, the University ought to pay more for staff who have a legitimate case for help, so that their rights to health care are not jeopardised. As tuition fees in English and Welsh higher education were raised substantially a few years ago, it is likely that this will become a more serious consideration in the future for those students who had to fund a significant percentage of their education from loans and who would be disadvantaged unfairly compared to early school leavers if morally significant debts were not taken into consideration.

Thirdly, the University must also consider that some staff must expend more resources to obtain an adequate level of health care compared to others. Some staff, for example, may 
have much more significant health problems compared to others that they cannot be held responsible for. Whereas the government and private insurance schemes should ideally protect those with greater health care needs, it seems reasonable to expect the University to help out where help by third parties is deemed to be inadequate. The University also has campuses overseas, namely in Malaysia and Singapore, where the cost of living differs from the cost of living in the UK. If some staff require less money to be provided with a basic standard of health care compared to others, this difference should be reflected in their wages, at least where a good case can be made that doing so outweighs the harm that such an adjustment might cause in maintaining economic inequalities between different countries.

Finally, if Newcastle University's current payment regime is unfair, the principle of restitutive justice demands that those who have benefited unfairly must compensate those who have been disadvantaged unfairly. Accordingly, some people may earn significantly less than the egalitarian baseline in the future. However, it is important to ensure that the extent to which some people's salaries are reduced to redress any historic injustices does not increase threats to workers' rights to health care overall.

So far the author has argued that decisions about people's salaries are best made by starting from an egalitarian baseline and that any changes from this baseline must be justified by reference to relative differences in controllable effort, duties in relation to unpaid work, morally significant debts, health care needs, and historic unfairness. A further qualification, however, will be required, as the scheme outlined so far fails to provide a satisfactory response to the 'brain drain' objection.

\section{The brain drain objection}


If the adoption of this pay system were to trigger a 'brain drain' whereby those who receive relatively high wages now leave the University in order to take on more lucrative jobs elsewhere, the University's quality would suffer. This is likely to result in a reduction in income, which would reduce every employee's salary. This levelling down objection must be taken seriously. If we assume the validity of the premise on which this objection relies, the University should also allow pay differentiation on the basis of success by rewarding those employees who are the most successful in bringing in income. This should be done not on the basis of the view that success ought to be rewarded, but on the basis of the view that not rewarding successful employees might jeopardise the rights to health care of all employees. The counterargument to this is that the state provides a safety net that secures rights to adequate health care for all, for example by looking after those who might lose their jobs because of the brain drain. This would render this objection invalid unless it was deemed that the state does not do enough to secure the right to health care for all. If we assume that the state does not do enough in this respect, the prima facie unjustifiable local (intraorganisational) inequality associated with rewarding those who are successful should be tolerated to avert either absolute poverty or total inequality (where the adoption of a local egalitarian policy would disadvantage members of one organisation relative to members of other organisations), subject to one condition: a convincing case should be made that the latter presents the greater evil. Put differently and more concisely, inequalities that cannot be justified locally may be justifiable to stave off greater threats to workers' rights to health care.

However, the premise on which the argument relies must be questioned also: what evidence do we have to suspect that such a brain drain would happen? If evidence could be presented to support the view that a shift to a locally implemented more egalitarian division of financial resources might cause a brain drain, there would be grounds for concern. However, evidence 
could be presented to support the contrary view, namely that adopting a more egalitarian pay structure may motivate workers to stay rather than to leave. As mentioned earlier, an organisation that pays workers the same amount per hour worked is Suma, a food wholesaler founded in Leeds in 1977. Suma had 153 workers in 2012 and experienced an increase in turnover from $£ 14.3$ million in 2002 to $£ 27.8$ million in 2011 , as well as an increase in its total wage bill from $£ 1.7$ million in 2002 to $£ 4.3$ million in 2011 (Corbett, 2013: 165-6). Having researched the organisation, Corbett writes that 'the equal wage structure includes gross wages of $£ 26,000$ per annum for a five day week, a profit related Christmas bonus, free cooked lunches, enhanced sick pay (three months on full pay), staff shopping at trade price, the option to take leave of up to six months, and a health plan' (Corbett, 2013; 175). His research also reveals that the equal pay structure that this organisation adopts is a significant 'source of pride' (Corbett, 2013: 175). These data might help to explain why more than a third of staff who worked for Suma in 1990 were still working for Suma in 2012 (Corbett, 2013: 165-70).

Whereas the example of Suma is no more than an anecdote because of its highly unusual pay structure, it reveals that it is by no means a certainty whether either the feared brain drain or the feared reduction in income would happen if the University were to develop a more egalitarian pay structure. If Suma's pay structure is cherished by many of its employees, some people might likewise be attracted to work and to continue working for the University precisely because of its superior pay policy. However, even if we accept that the feared brain drain would happen, and that this would trigger a reduction in the University's income and in the wages paid to its workers, the question must be asked whether the University should be concerned about such a reduction in light of the fact that it could currently pay every worker much more than the $£ 7.85$ hourly living wage rate that has been set by the Living Wage 
Foundation for workers outside London (Living Wage Foundation, undated). In 2014, the University spent $52 \%$ of its income on paying staff, to provide for the total of 5,081 full time equivalent staff that it possessed on 31 July 2014 (Newcastle University, 2014). Its wage bill amounted to $£ 228.2$ million in the academic year 2013-14 so that the average gross salary of each full time employee was just over $£ 44,912$. This figure substantially exceeds the average gross annual salary of full time employees in the UK in the year leading up to 5 April 2013, the latest year for which data are available at the time of writing, which was $£ 26,884$ (Office for National Statistics, 2013). Some staff are expected to work 37 hours per week, and others 40 hours per week, but the proportion of staff within each category fluctuates. If we adopt a conservative estimate by assuming that everyone works 1,744 hours per year - the number of hours that people who are on the highest salary points are expected to work - the average gross hourly salary would amount to $£ 25.75$. In addition, the University also offers employees the option to be rewarded with a contribution to a defined pension scheme at a percentage of their salary, which might be conceived in terms of deferred pay. This shows that the hourly wage that a Newcastle University employee would be paid if the income that is spent on salaries were divided equally substantially exceeds the 2014 national living wage hourly rate of $£ 7.85$. The author's suggestion, therefore, is that the University should alter its pay policy by a gradual transition towards a more egalitarian pay structure. However, the consequences of doing so should be monitored carefully to avoid the possibility that too great a concern with local inequality might marginalise other threats to the right to adequate health care that every human being ought to possess, such as the threats of global inequality and absolute poverty. These threats might increase if the advent of a more egalitarian local ethos were to trigger a decline in the quality of the University's teaching and research. 
Two small steps in the direction of a more egalitarian pay structure were taken when, in August 2013, some workers received a pay increase as the lowest point on the common pay spine became obsolete and when, in November 2013, some of the lowest paid staff were paid up to $£ 300$ extra. The latter, however, was no more than a one-off ex gratia payment (Newcastle University, 2014: 32). Consequently, every worker is guaranteed to earn at least $£ 8.83$ as the lowest point on the common pay scale produced a salary of $£ 14,257$ where someone on that point of the scale is expected to work 1,613 hours per year. This is a step in the right direction as, on 16 August 2012, the University had 404 staff whose hourly pay was less than the living wage (What Do They Know, undated). However, at the same time, the hourly pay difference ratio between the highest paid member of staff and the lowest paid was 17.8 to one (Times Higher Education, undated). Recent research has also revealed that the vice chancellor of Newcastle University earns 5.9 times more than what the average member of staff is paid, and that there are 112 workers who are paid more than $£ 100,000$ per year (University and College Union, 2015: 36).

In the author's view, it is unlikely that threats to people's rights to health care would increase if the University took further steps in the direction of an egalitarian pay structure. It is clear, however, that revising pay structures will not be the only thing that is required to develop a more egalitarian ethos. A further measure, for example, would be to drop academic titles as it is unclear why those who have obtained particular degrees or professional positions should expect to be addressed differently compared to everyone else merely because they have those degrees or positions (Morand and Merriman, 2012: 138). There is a significant danger that using those titles serves to maintain and reinforce traditional divisions between superior and subordinate people. In the interest of equality, the name of 'advisor' may also be preferred to that of 'supervisor'. 


\section{Conclusion}

As the right to health care can, in many situations, only be respected through the availability of adequate resources and as many resources can only be procured by means of money in the prevailing economy, any initiative to promote fairness must tend carefully to the grossly unequal distribution of resources across people and societies. This has been perceived by the NFC, which recognises that the health of many people in Newcastle is jeopardised by an absolute and relative lack of resources, which is why it recommended that organisations should implement a living wage as the minimum wage that all workers should enjoy, as well as reduce pay ratios. These recommendations were compared with the alternative distribution scheme adopted by Suma, which uses an unqualified 'equal pay for equal time' principle to distribute wages. Whereas this principle might appeal to those who follow Cohen in adopting the view that an egalitarian ethos should guide the implementation of Rawlsian justice, the author questioned the desirability of using this principle in relation to the issue of how Newcastle University ought to divide its wage bill. The author argued that decisions about people's salaries are best made by starting from an egalitarian baseline and that any changes from this baseline must be justified by reference to relative differences in controllable effort, duties in relation to unpaid work, morally significant debts, health care needs, and historic unfairness. Newcastle University's Council must justify deviations from the proposed salary scheme by arguing that the prima facie wrongness of pay inequality outside these parameters is outweighed by the greater good that might be served, and the same applies to other organisations.

\section{References}


Arnold, S. (2012) 'The difference principle at work', The Journal of Political Philosophy, 20(1): 94-118.

Basic Income Earth Network (undated) http://www.basicincome.org/bien/

Cohen, G. (1997) 'Where the action is: on the site of distributive justice', Philosophy \& Public Affairs, 26(1): 3-30.

Corbett, S. (2013) The social quality of participatory democracy: social empowerment in the workplace and local community. A thesis submitted for the degree of Doctor of Philosophy $(P h D)$, University of Sheffield: Department of Sociological Studies.

Deckers, J. (2011) 'Negative "GHIs," the right to health protection, and future generations', Journal of Bioethical Inquiry, 8(2): 165-76.

European Social Charter of the Council of Europe (undated) http://conventions.coe.int/Treaty/en/Treaties/Html/035.htm

Himmelweit, S. (1995) 'The discovery of "unpaid work": the social consequences of the expansion of "work", Feminist Economics, 1(2): 1-19.

Living Wage Foundation. (undated) http://www.livingwage.org.uk/calculation

Living Wage Independent Advisory Panel to Newcastle City Council (2012) A Living Wage for Newcastle.

Marmott, M., Stansfeld, S., Patel, C. et al (1991) 'Health inequalities among British civil servants: the Whitehall II study', The Lancet, 337(8754): 1387-93.

Morley, L. (2014) 'Lost leaders: women in the global academy', Higher Education Research \& Development, 33(1): 114-128.

Newcastle City Council and Newcastle University (2012) Fair share, fair play, fair go, fair say. Report of the Newcastle Fairness Commission.

Newcastle University (2014) http://www.ncl.ac.uk/foi/publicationscheme/spending/financialstatements.htm 
Office for National Statistics (2013) Statistical bulletin: annual survey of hours and earnings, 2013. Provisional results. http://www.ons.gov.uk/ons/rel/ashe/annual-survey-of-hours-andearnings/2013-provisional-results/info-ashe-2013.html

Pickard, L. (2015). 'A growing care gap? The supply of unpaid care for older people by their adult children in England to 2032', Ageing and Society, 35(1): 96-123.

Rawls, J. (1971) A theory of justice, Cambridge, MA: The Belknap Press of Harvard University Press.

Rawls, J. (1999) A theory of justice (revised edition), Cambridge, MA: Harvard University Press.

Sandel, M. (2012) What money can't buy, London: Allen Lane.

$\begin{array}{llll}\text { Times } & \text { Higher } & \text { (undated) }\end{array}$ http://www.timeshighereducation.co.uk/download?ac $=8048$ University and College Union (2015) Transparency at the top? Senior pay and perks in UK universities. Available at: http://www.ucu.org.uk/media/pdf/0/0/ucu_transparencyatthetop_mar15.pdf What Do They Know (undated) https://www.whatdotheyknow.com/request/living_wage_8 Whittaker, M., and Hurrell, A. (2013) Low pay Britain 2013, London: The Resolution Foundation. Available at: http://www.resolutionfoundation.org/publications/low-pay-britain$2013 /$

Wilkinson, R., and Pickett, K. (2010) The spirit level. Why equality is better for everyone. London: Penguin Books. 